\title{
Hatay ili sığır yetiştiriciliği işletmelerinde pazarlama yapısı, sorunlar ve çözüm önerileri: Payas ilçesi örneği
}

Marketing structure, problems and solutions in cattle breeding enterprises in Hatay province: Example of Payas district

\section{Nuran TAPKI ${ }^{1}$ (D) , Erdal DAĞISTAN ${ }^{1}$ (D) Nurcan ERTÜRKÜNER ${ }^{2}$ (D) Ahmet Anıl ERTÜRKÜNER ${ }^{2}$ (D)}

${ }^{1}$ Hatay Mustafa Kemal University, Faculty of Agriculture, Department of Agriculture Economics, Antakya-Hatay, Turkey.

${ }^{2}$ Ministry of Agriculture and Forestry, Payas District Directorate, Payas-Hatay, Turkey.

\section{MAKALE BILGISI / ARTICLE INFO}

\section{Makale tarihçesi / Article history:}

DOI: $10.37908 /$ mkutbd. 757252

Geliş tarihi / Received:07.07.2020

Kabul tarihi/Accepted:14.08.2020

\section{Keywords:}

Hatay, warketing structure, enterprise, cooperative, association, consumer.

\footnotetext{
Corresponding author: Nuran TAPKI

$\varangle:$ ntapki@mku.edu.tr
}

\section{Ö ZET / A B STR A C T}

\footnotetext{
Atıf / Citation: Tapkı N, Dağıstan E, Ertürküner N, Ertürküner AA (2020) Hatay ilindeki sığır yetiştiriciliği işletmelerinde pazarlama yapısı, sorunlar ve çözüm önerileri: Payas ilçesi örneği. MKU. Tar. Bil. Derg. 25(3) : 413-421. DOI: 10.37908/mkutbd.757252 


\section{Giriş}

Tarım sektörü Dünya GSH'nın \%3.2'sini oluştururken, hayvancılık sektörü toplam tarımsal GSH'nın \%37.0'lik bölümünü karşılamaktadır (FAO, 2017). Bu oran $A B$ ülkelerinde \%55.0, $\mathrm{ABD}$ 'de $\% 46.0$, gelişmekte olan ülkelerde ise \%24.0 civarındadır (FAO, 2017; Anonim, 2018). 2017 yılı FAO verilerine göre dünyada 1.5 milyar baş sığır bulunmaktadır. Dünya süt üretimi 828 milyon ton, et üretimi ise 334 milyon ton olarak belirlenmiştir (FAO, 2017; Anonim, 2018).

Insan beslenmesinin temel kaynağını bitkisel ve hayvansal ürünler oluşturmaktadır. Hayvansal ürünler insan sağlığı için gerekli olan birçok besin elementini içinde bulundurmaktadır. Bu besin elementleri et, süt, yumurta gibi ürünlerle vücudumuza alınmakta ve insan sağlı̆ı̆na ve yaşamına çok önemli katkılar yapmaktadır. Beyin gelişiminin sağlanması için gerekli olan amino asitlerin önemli bir bölümü hayvansal ürünlerle alınmaktadır. Dünya sağlık örgütüne göre sağlıklı bir bireyin vücut ağırlığının her bir kilogramı için 1 gram protein alması ve bununda \%42.0'sinin hayvansal kaynaklı olması gerektiği öngörülmektedir (Anonim, 2018).

Türkiye gibi gelişmekte olan ve giderek yükselen ülkelerde hayvancllık sektörü sağlığa ve beslenmeye yapmış olduğu katkı yanında, ekonomik kalkınmaya yapmış olduğu katkı bakımından da önemlidir. Sektör, et, süt, deri, kozmetik, ilaç sanayi gibi sanayi dallarına hammadde sağlamakta, çayır ve mera alanlarını değerlendirmekte, ihracata katkıda bulunmakta, özellikle kırsal alanlarda istihdama katkı sağlamaktadır (Aral ve Cevger, 2000; Sever ve ark., 2017a).

Türkiye'de ekonomik refah ve sosyal hayat geliştikçe ve tüketici bilinç düzeyi arttıkça hayvansal ürünlere olan talep ve bu ürünlerden beklenen kalite arzusu yükselmektedir. Artan talebe karşılık üretimin artması gerekmektedir. Bu nedenle çoğunluğunu kırsal kesimin oluşturduğu sığırcılık işletmelerinin geleneksel yapıdan çıkarak bilinçli ve gelişmelere açık bir yapıya dönüşmesi verimlilik ve kalite artışına olumlu yansıyacaktır (Günlü ve ark., 2006; Sever ve ark., 2017a). Ancak hayvansal üretim dalında yapısal birtakım sorunlar mevcuttur. Bu sorunlardan en önemlileri; işletmelerin örgütlenme bakımından yetersiz olması ve pazarlama sorunları olarak belirtilebilir. Belirtilen sorunlar ürün fiyatlarını olumsuz etkilemekte ve üretici açısından mağduriyetler oluşmaktadır. $\mathrm{Bu}$ nedenle üreticiler desteklenirken üretim maliyetlerinin, üreticinin faaliyetini devam ettirmesini sağlayacak fiyat düzeyinin ve pazarın mutlaka dikkate alınması gerekmektedir (Demir ve ark., 2014; Sever ve ark., 2017a).
Hayvansal ürün üretim miktarlarının arttırıması, bunun yanında kaliteli ürün üretiminde maliyetlerin düşmesi üretici açısından olduğu kadar tüketiciye de olumlu yansımalar sağlayacaktır. Ayrıca ürünün üreticiden tüketiciye ulaşması aşamasında üretimde yaşanan sorunlar kadar, pazarlama açısından yaşanacak sorunlar ve bunların çözümü hem üretici hem de tüketici açısından gereklidir. Literatürde büyükbaş hayvancılık yetiştiriciliği konusunda yapılmış birçok çalışma mevcuttur. Koçyiğit ve ark. (2015), Türkiye ve Erzurum'da büyükbaş hayvancılığın durumunu ele almış, Erzurum'da büyükbaş hayvan yetiştiriciliğinde yaşanan sorunları incelemiş ve büyükbaş hayvancılığın gelişimine yönelik çözüm önerileri sunmuşlardır. Erzurum ilinde büyükbaş hayvancllıkta kaba ve kesif yem üretiminin arttırılmasının, ticari amaçlı olarak sığır yetiştiriciliğinin teşvik edilmesinin, çoban ya da sürü yetiştiriciliği mesleğinin geliştirilmesinin ilin hayvancılığını kâra geçireceği belirlenmiştir. Şahin ve Gürsoy (2016), Iğdır ilinde 86 işletmede süt sığırcılığı işletmelerinin sosyoekonomik yapılarını incelemiş, işletmelerin yaşadıkları pazarlama sorununu aşmaları için örgütlenmenin gerektiğini, ayrıca yörede yoğun olarak meralardan yararlanılmasına rağmen kesif yem masraflarının yüksek olduğunu, Sever ve ark. (2017b), hem süt, hem de sığır besiciliği yapan işletmelerin önemli bir bölümünün tarımsal kuruluşlara üye olduklarını, işletmelerin genellikle küçük ve orta büyüklükte olduğunu, sığır işletmelerinin önemli bir bölümünün devletten destek ve teşvik beklediklerini belirlemişlerdir. Sever ve ark. (2017a), Aksaray ilinde sığır işletmelerinin üretim ve pazarlama yapılarını inceledikleri çalışmada kümeleme analizi yapmışlar, işletmeleri iki kümeye ayırmış ve birinci küme işletmelerin daha büyük işletmeler olduğunu belirtmişlerdir. Birinci kümedeki işletmeler yem fiyatlarının yüksek olduğu yargısına daha çok katılmış, birinci kümedeki işletmeler, ikinci kümedekilere göre kredi faiz oranlarını daha yüksek olduğunu ifade etmişlerdir. İşletmeler besicilik konusunda kalifiye elemanının eksik olduğunu, besicilik ve süt sığırcılığında verilen desteklerin yetersiz olduğunu belirtmişlerdir. Göçoğlu ve Gül (2019), Uşak ilinde 127 işletme sahibi ile anket çalışması yaparak Uşak ilinin süt sığırcılığı işletmelerinin yapısını ortaya koymuşlardır. İşletmelerde toplam gelirde tarımın çok büyük payının olduğu belirlenmiş ve işletmelerin GSÜD, GSH, Saf Hasıla, Tarımsal Gelir ve Toplam Aile Geliri hesaplanmıştır. Yılmaz ve ark. (2020), Iğdır ilinde sığır yetiştiriciliği yapan işletmelerin yapısını ve mevcut durumunu incelemişlerdir. Araştırma sonuçları yetiştiricilerin hayvan bakımı ve beslenme konusunda yeterli bilgiye ve araziye sahip olduklarını ve modern çiftlikler kurmaları 
gerektiğini ortaya çıkarmıştır. Dossa ve ark. (2015), Burkina Faso'da sığır yetiştiriciliği ve sığır yetiştiricilik sistemlerini kent içinde ve gelişmemiş kırsal alanlarda inceleyerek karşılaştırmalar yapmıştır. Afridi ve ark. (2009), Pakistan'ın kuzey bölümünde faktör verimliliği ve maliyet tahmini konulu çalışmalarında hayvancilık maliyetlerini, hayvancılık işletmelerinin genel özelliklerini, hayvansal üretim maliyetlerini ve gelirlerini tahmin etmeyi, hayvansal üretim üzerine etkili olan faktörleri ve katkılarını belirlemeyi amaçlamıştır. Kumar ve ark. (2015), çiftçilerin geçim koşullarının iyileşmesinde sürdürülebilir temelde kooperatiflerin rolünü incelemişlerdir. Çalışma sonucunda, Hindistan'da başarılı bir kooperatif hareketinin sadece Hindistan'ın kırsal kesimlerinde geçim güvenliğini sağlamakla kalmayacağı, aynı zamanda diğer benzer ülkelerin kırsal geçim kaynaklarının iyileştirilmesine de yardımcı olacağı sonucunu ortaya çıkarmışlardır.

Bu çalışmada, Hatay ili Payas ilçesinde büyükbaş hayvan yetiştiricilerinin üretmiş oldukları ürünler için ürün satış yerleri ve şekilleri, örgütlenme ve örgütlenmeye bakış açıları ve ilçede yaşadıkları pazarlama sorunlarını belirlemek ve çözüm önerileri sunmak amaçlanmıştır.

\section{MATERYAL ve YÖNTEM}

Araştırmanın ana materyalini Hatay ili Payas ilçesinde büyükbaş hayvancılık yapan ve Damızlık Sığır Yetiştiricileri Birliğine üye olmayan işletmecilerle yapılan yüz yüze görüşmeler sonucunda elde edilen birincil veriler oluşturmuştur. ilıçede damızlık sığır yetiştiricileri birliğine üye olmayan işletmelerin seçilmesinde amaç literatürde "Hatay ili Damızık Sığır Yetiştiricileri Birliği Üyesi İşletmelerin Sosyo-Ekonomik Özellikleri" isimli çalışmanın bulunmasındandır (Tapkı ve ark., 2018). Bireysel görüşmeler 2020 yılında araştırıcılar tarafından yapılmıştır. Anket soruları amaç, konu ve ana kütle özellikleri dikkate alınarak hazırlanmıştır.

Araştırmada büyükbaş hayvancılık faaliyetinde bulunan işletmeler seçilmiştir. İşletmeler damızlık sığır yetiştiricileri birliğine üye değildir. İşletmelerin sayısının belirlenmesinde Payas illçe Tarım ve Orman Müdürlüğü kayıtlarından yararlanılmıştır. İlçede 201 adet büyükbaş hayvancılık faaliyeti yapan işletme bulunmakta olup, çalışmanın ana kitlesini bu işletmeler oluşturmuştur.
İşletmeler hayvan sayılarının fazla olduğu merkez ilçe ve Sincan, Çağlalık, Kozludere köylerinden seçilmiştir.

Örnek büyüklüğünün tespitinde Basit Tesadüfi Örnekleme yöntemi kullanılarak aşağıdaki formülden yararlanılmıştır (Yamane, 2010; Yılmaz ve ark., 2020). Tespit edilen sayıya göre işletmeler ana kitleden seçilmiştir.

$$
n=\frac{N * t^{2} * p^{*} q}{(N-1) d^{2}+* t 2 * p * q}
$$
$\mathrm{N}$ : Evren büyüklüğü
$\mathrm{n}$ : Örnek büyüklüğü
$\mathrm{d}$ : Kabul edilen örnekleme hatası
$\mathrm{p}$ : Hesaplanması istenen oran (0.3)
$q: 1-p$
$\mathrm{t}$ : Belirli serbestlik derecesinde ve saptanan yanılma düzeyinde $t$ tablosunda bulunan teorik değer $\% 95$ güven düzeyinde ( $\mathrm{t}=1.96),+/-\% 10$ hata oranı ile örnek büyüklüğü 58 olarak hesaplanmış ancak çalışmada 63 adet işletmeciye anket uygulanmıştır.

\section{BULGULAR ve TARTIŞMA}

\section{işletmelerin demografik yapısı}

Üreticilerin \%61.9'u $25-50$ yaş arasında,\%36.5'i ise 50 ve üzeri yaştadır. Illkokul mezunu üreticilerin oranı \%66.6, ortaokul ve lise mezunu üreticilerin oranı ise $\% 12.7$ 'dir. Yüksekokul mezunu üreticilerin ve üniversite mezunu üreticilerin oranı ise \%3.2'dir. Ailelerde ortalama birey sayısı 4.4 kişidir. İşletmeciler tarımsal faaliyetle ortalama 17.4 yıl, hayvancılıkla ise 16.7 yıldır uğraşmaktadır (Çizelge 1). Iğdır ilinde yapılan bir çalışmada aile genişliği 5.42, işletme sahiplerinin hayvancılıkla uğraşma yılı 25.74 yıldır (Şahin ve Gürsoy, 2016). Ankara ve Aksaray'da yapılan bir çalışmada işletmelerde ortalama birey sayısı sırasıyla 4.9 ve 5.5 kişidir (Tatar, 2007). Muğla ilinde yapılan bir çalışmada işletmecilerin ortalama deneyim süreleri 22.3 yıldır (Aydın ve Keskin, 2019). Erzurum ilinde yapılan bir çalışmada ise aile bireylerinin sayısı ortalama 5.81 olarak bulunmuştur (Kılıçtek ve Aksoy, 2019). 
Çizelge 1. Sığır yetiştiricilerinin demografik ve ekonomik özellikleri

\begin{tabular}{lcclcc}
\hline Yaş & $\mathbf{f}$ & \% & Gelir Durumu & f & \% \\
\hline $0-24$ & 1 & 1.6 & 999 TL ve altı & 13 & 20.6 \\
$25-49$ & 39 & 61.9 & $1.000-1.999$ & 35 & 55.6 \\
$50-+$ & 23 & 36.5 & $2.000-2.999$ & 11 & 17.4 \\
Toplam & 63 & 100.0 & $3.000-3.999$ & 2 & 3.2 \\
Eğitim Düzeyi & $\mathbf{f}$ & $\%$ & $4.000-+$ & 2 & 3.2 \\
Illkokul & 42 & 66.6 & & & \\
Ortaokul & 8 & 12.7 & Ailede yaşayan ortalama birey sayısı & 4.4 \\
Lise & 8 & 12.7 & Ort.Tar. Faaliyet yılı & 17.4 \\
Yüksekokul & 2 & 3.2 & Ort. Büyükbaş hayvancılık uğraşı yılı & 16.7 \\
Üniversite & 2 & 3.2 & & & \\
Okuryazar & 1 & 1.6 & & & \\
Toplam & 63 & 100.0 & & & \\
\hline
\end{tabular}

İsletmelerde tarımsal ve hayvansal faaliyet yapma durumu

Işletmecilerin 6 (\%9.5) tanesi hayvancılık yanında tarımsal üretim yapmaktadır. İki işletme buğday (\%3.1), üç işletme fasulye ve bir işletme zeytin üretimi yaptığını belirtmiştir. İşletmecilerin 41 tanesi sadece hayvancllık yaptıklarını (\%65.1), 19 tanesi (\%30.2) hayvancılık yanında başka bir işte ücretli olarak çalıştıklarını, bir işletmeci hayvancılık yanında işveren olduğunu belirtmiştir (Şekil1). Incelenen işletmelerde ortalama 10.1 adet büyükbaş hayvan bulunmaktadır. Gökçeada'da yapılan bir çalışmada işletmelerde hayvancılık faaliyetinin yanında yem bitkisi üretimi yapıldığı arpa, yonca ve fiğ üretildiği belirtilmiştir (Aktürk ve ark., 2005).

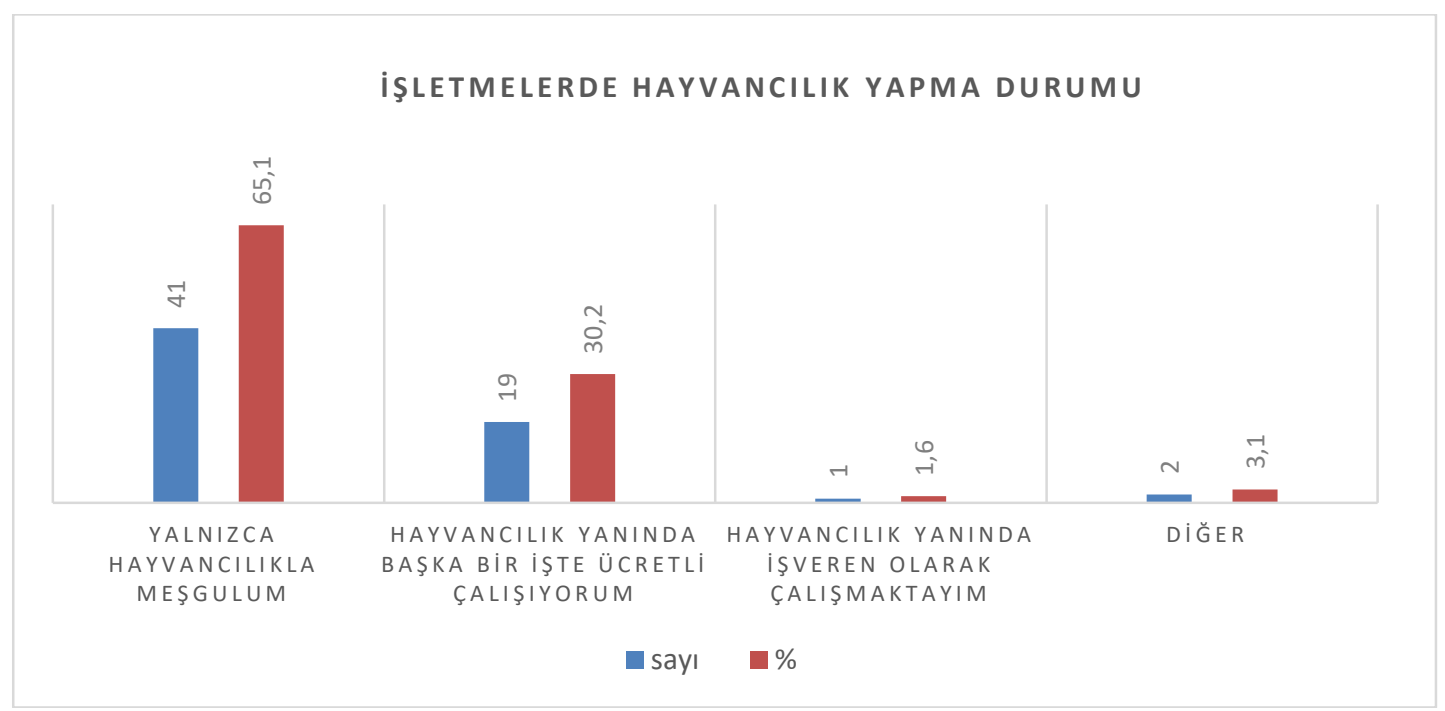

Şekil 1. İşletmecilerin hayvancılık yapma durumu

Incelenen işletmelerin 41 tanesi köylerde, 22 tanesi ise ilçe merkezinde faaliyet göstermektedir. Köylerde hayvancılık yapan işletmelerin ilçe merkezlerine uzaklıkları ortalama $4.32 \mathrm{~km}$ 'dir. İşletmelerin ortalama arazi büyüklüğü 1.45 dekar olarak hesaplanmıştır. İ̧̧letmelere ücretli iş̧̧i çalıştırma durumları sorulmuştur. Dört işletme birer işçi çalıştırdıklarını belirtmiştir. Incelenen işletmelerde hayvancilık; süt sığırcılı̆̆ı, besi sığırcılığı, süt ve besi birlikte ve küçükbaş hayvancılık olarak yapılmaktadır. 43 işletme sadece süt sığırcılı̆̆ı ile uğraşmaktadır (\%68.3). Yalnızca besi işletmesi üç (\%4.8), süt ve besi beraber 17 (\%26.9) işletmede yapılmaktadır Aksaray ilinde yapılan bir çalışmada araştırmaya katılan 81 adet işletmenin \%9.9'u besi, \%28.4'ü süt ve \%61.7'si ise besi ve süt sığırcılı̆̆ını birlikte yapmaktadır (Sever ve ark., 2017). İşletmelerde büyükbaş hayvan yanında küçükbaş hayvan azda olsa bulunmaktadır. İşletmelerde ortalama 10.1 adet büyükbaş hayvan mevcuttur. Ortalama işletme başına düşen koyun sayısı 3.2, keçi sayısı, 0.9, tavuk sayısı ise $8.9^{\prime}$ dur. İşletmelerde 1-5 büyükbaş hayvanı bulunan işletme sayısı 30 (\%47.6), 620 arası 25 (\%39.7), 21-30 arası 5 (\%7.9), 31-50 arası bir 
(\%1.6), 51 ve üzeri hayvanı olan işletme sayısı ise iki (\%3.2) adettir. Iğdır ilinde yapılan bir çalışmaya göre işletmelerde bulunan ortalama büyükbaş hayvan sayısı 10.25 olarak tespit edilmiş olup, işletmelerde süt sığırcılığı yanında besicilik yapıldığı belirtilmiştir. İşletmelerde bulunan hayvan sayıları bakımından çalışma ile mevcut araştırma benzerlik göstermektedir (Şahin ve Gürsoy, 2016).

\section{Işletmelerde hayvansal ürünlerin pazarlanma durumu Süt pazarlama durumu}

Çizelge 2. Hayvansal ürünlerin değerlendirilmesi

\begin{tabular}{lcc}
\hline Hayvansal ürünlerin değerlendirilmesi & Sayı & $\%$ \\
\hline Satış amacı ile & 59 & 93.7 \\
Evde aile tüketimine yönelik & 12 & 19.0 \\
Hayvansal üretimde girdi materyali & 6 & 9.5 \\
Toplam & 77 & \\
\hline
\end{tabular}

Not: işletme sahipleri birden fazla seçenek belirtmiştir.

Incelenen işletmelerde üretilen toplam sütün \%77.4'ü çiğ olarak satılmakta \%22.6'sı ise evde çeşitli şekillerde değerlendirilmektedir. Satılmayan çiğ sütün bir kısmı evde buzağılara verilmekte, aile tüketiminde kullanılmakta, peynir ve yoğurda dönüştürülerek satılmaktadır (Çizelge 3). Iğdır ilinde yapılan bir çalışmada, mevcut araştırmada olduğu gibi işletmeler süt üretimi yanında peynir, tereyağı üretimi yapmakta, bir kısmı da işletme içinde tüketilmektedir. Evde tüketilmeyen ürün pazarlanarak değerlendirilmektedir (Şahin ve Gürsoy, 2016). İncelenen işletmelerde aylık ortalama süt üretim miktarı $974.1 \mathrm{~kg}$ olup, \%77.0 oranında satışa sunulmakta, \%7.4'ü aile tüketiminde kullanılmakta, \%6.7'si buzağılara verilmekte, \%8.9'u ise tereyağı ve peynir yapımında kullanılmaktadır (Çizelge 3). Incelenen işletmeler daha güvenli olması (\%12.7), daha yüksek fiyata satabilmeleri (\%55.6), ulaşım sorunu yaşamamaları (\%4.8), satış garantisi olması (\%7.9) ve zorunlu olmaları (\%19.0) gibi sebeplerle süt satışını işletmede yaptıklarını belirtmişlerdir. Incelenen işletmelerde sütün kilogramı ortalama 2.77 TL'ye satılmaktadır. İsletme sahiplerinin \%74.6'sı süt fiyatlarını
Işletmelerde ürünler çeşitli şekillerde değerlendirilmektedir. İşletmeler ürünleri nasıl değerlendiriyorsunuz sorusuna birden fazla seçenek belirterek cevap vermiştir. İşletmelerin \%93.7'si ürünleri satarak , \%19.0'u evde aile tüketimine yönelik olarak ve \%9.5' $i$ ise hayvansal üretim için girdi materyali olarak değerlendirdiklerini belirtmişlerdir (Çizelge 2). İncelenen işletmelerde toplam günlük süt üretim miktarı $2372 \mathrm{~kg}$, yıllık süt üretim miktarı ise $623250 \mathrm{~kg}$ olarak hesaplanmıştır. düşük bulurken, \%25.4'ü normal bulmaktadır. Süt fiyatını düşük bulan işletmeler, sütün kilogram fiyatının ortalama $3.58 \mathrm{TL}$ düzeyinde olması gerektiğini vurgulamışlardır. Incelenen işletmelerde süt satışları 46 işletmede (\%73.0) peşin, 24 (\%38.1) işletmede vadeli, beş işletmede (\%7.9) ise hem peşin, hem vadeli olarak yapılmaktadır. İşletmeler ürettikleri çiğ sütü $\% 73.0$ oranında doğrudan tüketiciye, \%27.0 oranında ise yerel toplayıcılara ve mandıralara satmaktadır. Iğdır ilinde yapılan bir çalışmada satılan sütlerin \%11.2 sinin mamule işlendiği, diğer kısımlarının ise çiğ süt şeklinde satıldığı, çiğ süt olarak satılan yerlerin toplayıcılar (\%81.3) ve mandıralar (\%7.5) olduğu belirtilmiştir (Yılmaz ve ark., 2020). Incelenen işletmelerden 2 tanesi mandıralara, 2 tanesi süt ticareti yapan işletmelere satış yaptıklarını belirtmiştir. Sütü alan mandıralar süt ürünlerine dönüştürdükten sonra tekrar piyasaya sunmaktadır. Ürünler pazarlama kanalı içinde farklı aracılar ile karşılaşabilmektedir. Böylece her kanalda sütün fiyatı farklılaşmakta ve kanal içinde bulunan aracılar farklı kar marjı elde etmektedir.

Çizelge 3. İşletmelerde sütün aylık kullanım durumu (kg)

\begin{tabular}{lcc}
\hline Çiğ sütün aylık kullanımı (ortalama) & Miktar & $\%$ \\
\hline Satılan süt & 974.1 & 77.0 \\
Aylık tereyağı ve peynir yapımı & 113.5 & 8.9 \\
Aile tüketimi & 93.3 & 7.4 \\
Buzağılara verilen süt & 84.4 & 6.7 \\
Aylık ortalama toplam & 1265.3 & 100.0 \\
\hline
\end{tabular}


Üreticilerin $\% 77.8^{\prime} i$ seyyar süt satıcılarının, $\% 9.5^{\prime} i$ mandıraların, \%6.3'ü fabrikaların, \%4.8'i marketlerin, \%1.6'sı ise üreticilerin karlı olduğu görüşünü savunmuştur.

\section{Canlı hayvan pazarlama durumu}

Incelenen işletmelerin hepsi canlı hayvan satışı yaptıklarını belirtmiştir. İşletmelerin \%95.2'si damızlık olarak ayırdıktan sonra geri kalanı sattığını, 3 tanesi (\%4.8) ise yarısını satıp, yarısını damızlık olarak ayırdığını belirtmiştir. Yapılan canlı hayvan satışlarının \%90.2'si kasaplara, \%9.8'i ise tüccarlaradır. Hayvanlar işletmede satılmakta ve ürün bedelleri $\% 76.2$ oranında peşin, $\% 22.2$ oranında vadeli, \%1.6 oranında ise hem vadeli hem de peşin olarak tahsil edilmektedir. İncelenen işletmeler işletme masraflarını karşılamak için (\%71.4), aile geçimini sağlamak için (\%68.3), hayvan beslenme giderleri için (\%31.7), hayvan sağlığı giderleri için (\%25.4) canlı hayvan satışı yapmaktadırlar (Çizelge 4).

Çizelge 4. Canlı hayvan satış nedenleri

\begin{tabular}{lcc}
\hline Canlı hayvan satış nedenleri & Sayı & $\%$ \\
\hline İşletme masraflarını karşılamak & 45 & 71.4 \\
Aile giderlerini karşılamak & 43 & 68.3 \\
Hayvan beslenme giderleri & 20 & 31.7 \\
Hayvan sağığı giderleri & 16 & 25.4 \\
Toplam & 124 & \\
\hline
\end{tabular}

Not: İsletme sahipleri birden fazla seçenek belirtmiştir.

\section{incelenen işletmelerde ürün fiyatlarının belirlenmesi ve kooperatifleşmeye yaklaşımları}

Tarım ürünleri fiyat oluşumunda birçok faktör etkili olmaktadır. Bunlar içinde arz ve talep durumu, girdi maliyetleri etkili olan en önemli faktörlerdendir. Üreticiler ürün fiyatlarının belirlenmesinde büyük alıcıların yani talep unsurunun etkili olduğunu belirtirken (\%87.3), satıcı (\%3.2) ve kooperatiflerin (\%9.5) etkisinin daha az olduğunu söylemişlerdir. İşletmelerin hiçbirinin kooperatif üyeliği bulunmamaktadır. Sadece bir işletme ziraat odasına üyedir. İşletmeler hepsi bulundukları yerde pazarlama kooperatifinin bulunmadığını ancak olmasının kendilerine olumlu katkı sağlayacağını belirtmiştir. İşletmeciler kooperatif kurulmasının pazarlama açısından yeni bir alternatif olacağını (\%34.9), ürün fiyatı oluşumunda düzenli ve dengeli bir artış sağlayabileceğini (\%58.8), üreticileri bilinçlendireceğini, pazar bilgilerine daha kolay erişebileceklerini (\%6.3) belirtmişlerdir (Şekil 2). Gökçeada'da yapılan bir çalışmada işletmelerin \%30.0'unun kooperatife, \%64.0'ünün ziraat odasına,\%2.0'sinin derneğe üye oldukları belirlenmiştir (Aktürk ve ark., 2005). Incelenen işletmelerde örgütlenme durumu oldukça yetersiz olup, Aktürk ve ark. (2005) tarafından yapılan çalışma ile mevcut araştırma sonuçları arasında farklılık bulunmaktadır.

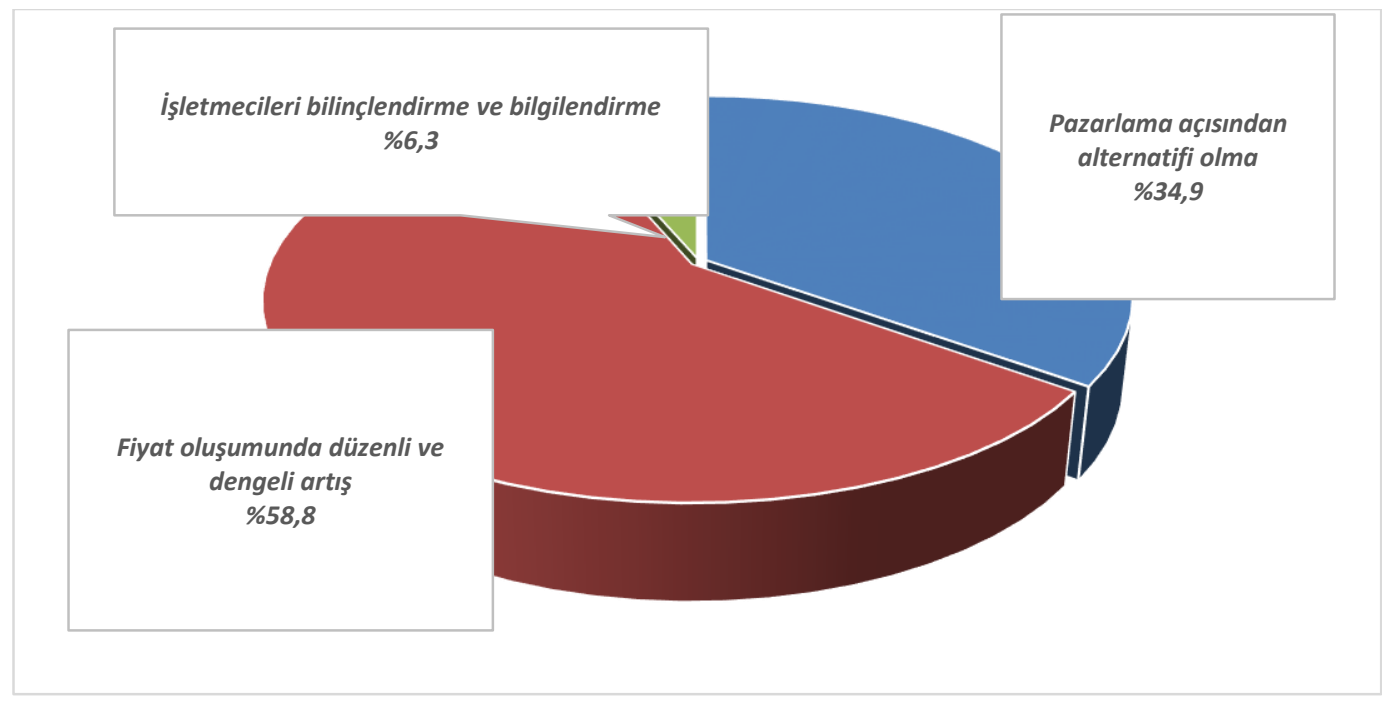

Şekil 2. Sığır yetiştiricilerinin hayvansal örgütlenme hakkındaki görüşleri 


\section{İşletmelerin büyükbaş hayvancılık yetiştiriciliğinden memnun olma durumu}

İncelenen işletmelere büyükbaş hayvan yetiştiriciliği yapmaktan memnun olup olmadıkları sorusu likert ölçeğine göre sorulmuştur. İşletmecilerin \%44.4'ü memnun olduklarını,\%31.7'si ise memnun olmadıklarını söylemiştir. Bu faaliyetten hiç memnun olmama durumu $\% 9.5$, çok memnun olma durumu \%7.9 olarak belirlenmiştir.

\section{İşletmelerin ürün pazarlama aşamasında yaşadıkları sorunlar}

İşletmeciler yaşadıkları pazarlama sorunlarına birden çok seçenek belirterek cevaplar vermişlerdir. Yaşadıkları en önemli sorun nakit yetersizliğidir (\%74.6). Önemli olan diğer sorunlar alıcı sayısının yetersiz oluşu (\%26.9), pazarlama için verilen desteklemelerin yeterli olmaması (\%19.0), pazarla ilgili bilgilere yeterince ulaşamamalarıdır (\%4.8) (Çizelge 5).

Çizelge 5. İşletmelerin pazarlama sorunları

\begin{tabular}{lcc}
\hline Pazarlama sorunu & Sayı & $\%$ \\
\hline Nakit yetersizliği & 47 & 74.6 \\
Alıcı sayısının yetersizliği & 17 & 26.9 \\
Desteklemelerin azlığı & 12 & 19.0 \\
Pazar bilgilerinin yetersizliği & 3 & 4.8 \\
Toplam & 79 &
\end{tabular}

Not: İ̧letme sahipleri birden fazla seçenek belirtmiştir.

Sonuç olarak, Payas ilçesi Hatay ilinin büyükbaş hayvancılık faaliyetinin yapıldığı ilçelerinden biridir. Illçede yapılan hayvancılık faaliyeti süt ve süt ürünleri üretim ve pazarlanması ve canlı hayvan yetiştiriciliği ve pazarlanmasına yönelik olarak yapılmaktadır. İlçede işletme sahiplerinin \%36.5'i 50 ve üzeri yaştadır. işletmecilerin hayvancılık faaliyetlerini ortalama 16.7 yıldır yapmakta oldukları belirlenmiştir. İncelenen işletmelerde ortalama 10.1 adet büyükbaş hayvan bulunmaktadır. Bu çalışma ile Hatay ili Payas ilçesinde damızlık sığır yetiştiricileri birliğine üye olmayan 63 adet işletmede büyükbaş hayvancılıkta ürün ve canlı hayvan pazarlama yapısı ortaya konulmuş ve üreticilerin pazarlama ile ilgili sorunları belirlenmiştir. Elde edilen sonuçlara göre ürünlerin pazarlanması ile ilgili üreticilere faydalı olacak bir pazarlama kooperatifinin bulunmadığı belirlenmiştir. Bu amaçla kurulacak kooperatifin işletmeler açısından çok olumlu olacağı ve ürün pazarlanmasında yeni bir alternatif olacağı, ürün fiyatlarının düzenli ve dengeli olarak artacağı, üreticilerin bilinç düzeyinin artacağı ve pazar bilgilerine daha kolay erişebilecekleri belirlenmiştir. Üreticilerin hayvansal ürünlerin pazarlamasında yaşadıkları en önemli sorunlar; desteklemelerin yeterli olmayışı, nakit yetersizliği, müşteri sayısının azlığı ve pazar bilgileri konusunda yetersiz kaldıklarıdır. Üreticilerin sahip oldukları yetiştiricilik ve üretim açısından bilgi eksiklikleri elde edilen ürün miktarı ve kalitesinde önemli kayıplara sebep olmaktadır. Bu konuyla ilgili olarak yapılacak faaliyet ve düzenlemeler sayesinde ortaya çıkan olumsuz durumların giderilmesi için belirli planlar yapılarak buna göre hareket edilmeli ve olumsuzluklar giderilmelidir. Hayvansal üretim yapan işletmeler açısından yem temini oldukça önemli bir konudur. Yem fiyatlarının yüksek olması, hayvan beslenmesi ve hayvansal ürünlerin üretim miktarı açısından en önemli sorundur. Kullanılan kaba ve kesif yem miktar ve kalitesi verimlilik üzerinde etkilidir. Yörede bu sorunun giderilmesi için daha fazla yem üretimi ve kalitenin yüksek olması ve işletmelerin yüksek yem maliyetlerinden zarar görmemeleri için gerekli teşvikler verilmelidir. Bunun yanında yem bitkilerinin doğru tekniklerle üretimi için gerekli olan eğitim çalışmalarının verilmesi de kaliteli ürün elde edilmesi ve pazarlanması açısından önemli olacaktır. İncelenen işletmelerde ürünlerin üretimi, işlenmesi ve pazarlanması noktalarında faaliyette bulunan üretici örgüt ve kooperatiflerinin olmayışı, pazarlama hizmetleri açısından etkinliği azaltmakta ve üreticilerin aracılar ve tüketiciler karşısında pazarlama gücünü zayıflatmaktadır. Bu amaçla kurulacak olan pazarlama kooperatifleri ve örgütleri sayesinde ürün pazarlama konusunda oluşan sorunların azalmasına zemin hazırlayacaktır. Pazar bilgilerine erişimde sorun yaşandığı görülmektedir. Pazar bilgilerinin toplanarak üreticilerin bundan yararlanması için etkili bir haberleşme ve bilgi ağı oluşturulması gerekmektedir. Bu sayede ürün fiyatlarının oluşumu ve üreticiyi tatmin edecek fiyatta alıcıya ulaşması, gereksiz aracıların ortadan kalkması ve üreticilerin daha çok gelir elde etmesi sağlanabilecektir.

\section{ÖZET}

Amaç: Bu çalışmada, Hatay ili Payas ilçesinde sığır yetiştiriciliği yapan ve Damızlık Sığır Yetiştiricileri Birliğine üye olmayan işletmelerde ürün pazarlama yapılarının 
ortaya konması amaçlanmıştır. Araştırmada, işletmecilerin pazarlama sorunları belirlenmiş ve çözüm önerileri sunulmuştur.

Yöntem ve Bulgular: Araştırmanın ana materyalini ilçede faaliyet gösteren 63 adet işletmeci ile yüz yüze yapılan anket çalışması sonucunda elde edilen birincil veriler oluşturmuştur. Örnek büyüklüğü basit tesadüfi örnekleme yöntemi kullanılarak belirlenmiştir.

Genel Yorum: İşletmecilerin \%61.9'unun yaşı, 25-50 yaş arasındadır. Işletmeciler ortalama 16.7 yıldır sığır yetiştiriciliği yapmaktadır. İşletmelerde ailedeki fert sayısı ortalama 4.4 kişidir. İşletmecilerin \%3.2'si üniversite mezunudur. İşletmelerde yıllık pazarlanan çiğ süt geliri ortalama $623.250 \mathrm{TL}$ 'dir. İşletmelerde aylık üretilen sütün \%77.0'si çiğ olarak pazarlanırken, \%8.9'u tereyağı ve peynire işlenerek pazarlanmaktadır. Süt satışları doğrudan tüketiciye (\%73.0), toplayıcılara ve mandıralara (\%27.0) yapılmaktadır. İşletmecilerin $\% 74.6$ 'sı süt fiyatlarını düşük olduğunu ifade etmiştir. Işletmeler süt ve süt ürünlerinin yanı sıra canlı hayvan satışı da yapmaktadır. İşletmecilerin \%90.2'si kasaplara satış yaparken, \%9.8'i tüccarlara satış yapmaktadır. İşletmeciler pazarlama kooperatiflerinin ve birliklerinin kendilerine özellikle fiyat oluşumunda (\%58.7), pazarlama konusunda alternatif pazarlar ve pazarlama kanalları bulma (\%34.9), işletmecileri bilgilendirme ve bilinçlendirme açısından faydalı olacağını belirtmişlerdir (\%6.3).

Çalışmanın Önemi ve Etkisi: Bu çalışma ile ilçede pazarlama kooperatifinin bulunmadığı, kurulacak bir kooperatifin ürün pazarlanmasında yeni bir alternatif olacağı, ürün fiyatlarının düzenli ve dengeli olarak artacağı, üretici bilinç düzeyinin artacağı, pazar bilgilerine daha kolay erişilebileceği belirlenmiştir. Işletmelerde hayvansal ürünlerin pazarlanmasında yaşanan en önemli sorunlar; desteklemelerin yeterli olmayışı, nakit yetersizliği, müşteri sayısının azlığı ve pazar bilgilerine erişim konusunda yetersizliktir. Çalışma ile İşletmelere sorunların çözümü için öneriler sunulmuştur.

Anahtar Kelimeler: Hatay, pazarlama yapısı, işletme, kooperatif, birlik, tüketici.

\section{ÇIKAR ÇATIŞMA BEYANI}

Yazar(lar) çalışma konusunda çıkar çatışmasının olmadığını beyan eder.

\section{ARAŞTIRMACILARIN KATKI ORANI BEYANI}

Yazarlar çalışmaya eşit oranda katkı sağlamış olduklarını beyan eder.

\section{KAYNAKLAR}

Afridi GS, Ishaq M, Ahmad S (2009) Estimation of Costs and Returns and Factor Productivity in Livestock Enterprise in Northern Areas, Pakistan. Pakistan J. Life Soc. Sci., 7(1): 43-51.

Aktürk D, Savran F, Hakyemez H, Daş G, Savaş T (2005) Gökçeada'da Ekstansif Koşullarda Hayvancilık Yapan İşletmelerin Sosyo-Ekonomik Açıdan Incelenmesi.

Tar. Bil. Derg., 11(3): 229-235.

Anonim(2018) Tarım İşletmeleri Genel Müdürlüğü, Hayvancilık Sektör Raporu. https://www.tigem.gov.tr/(Erişim Tarihi:12.05.2020).

Aral S, Cevger Y (2000) Türkiye'de Cumhuriyetten Günümüze Gözlenen Hayvancılık Politikaları. Türkiye 2000 Hayvancılık Kongresi, 31 Mart-02 Nisan 2000, Ankara.

Aydın M. K, Keskin M (2019) Muğla ilinde Süt Sığırı Yetiştiriciliğinin Mevcut Durumu, Bazı Verim ve Yapısal Özellikleri. Lalahan Hay. Araşt. Enst. Derg., 59(2): 57-63.

Demir P, Aral Y, Sarı̈zkan S (2014) Kars ilii Süt Sığırcılık İşletmelerinin Sosyo-Ekonomik Yapısı ve Üretim Maliyetleri. YYU Tar. Bil. Derg., 25(1): 1-6.

Dossa L.H, Sangare M, Buerkert A, Schlecht E (2015) Intra-urban and Peri-urban Differences in Cattle Farming Systems of Burkina Faso. Land Use Policy, 48: 401-411

FAO (2017) Food and Agriculture Organization of the United Nations. http://www. fao. org. (Erişim Tarihi: 5 Mayıs 2019).

Göçoğlu I, Gül M (2019) Uşak ilinde Süt Sığırcılığı İşletmelerinin Ekonomik Yapısı. Mustafa Kemal Üniversitesi Tar. Bil. Derg., 24(3): 260-267.

Günlü A, Atasever M, Karakaya Y (2006) Erzurum ili Hayvancılığının Yapısal Özellikleri ve Yakın Gelecekteki Durumu Üzerine Genel Değerlendirme. Atatürk Üniversitesi Vet. Bil. Derg., 1(3-4): 55-68.

Kılıçtek S, Aksoy A (2019) Erzurum illi Süt Sığırcılığı İşletmelerinin Yenilikleri Benimseme Açısından Değerlendirilmesi. Türk Tar. Doğ. Bil. Derg., 6(3): 424431.

Koçyiğit R, Aydın R, Diler A (2015) Erzurum ili Büyükbaş Hayvancılığının Durumu ve Gelişmesine Yönelik Öneriler. Alınteri Derg., 29(B): 34-46.

Kumar V, Wankhede K.G, Gena H.C (2015) Role of Cooperatives in Improving Livelihood of Farmers on Sustainable Basis. Am. Educ. Res. J., 3(10): 1258-1266.

Sever E, İğdeli A, Han V (2017a) Aksaray illi Sığır Işletmelerinin Üretim ve Pazarlama Sorunları. J. Adv. VetBio Sci. Tech., 2(2): 10-23. 
Sever E, İğdeli A, Han V (2017b) Aksaray ili Sığır İşletmelerinin Sosyo Ekonomik Analizi. Adv. VetBio Sci. Tech., 2(3): 1-11.

Şahin K, Gürsoy AK (2016) Iğdır illi Süt Sığırcılığı İşletmelerinin Sosyo Ekonomik Yapısı. Nevşehir Bil. Tek. Derg., TARGiD Özel Sayı, 118-129.

Tapkı N, Tapkı I, Dağıstan E, Selvi M.H, Kaya A, Güzey YZ, Demirtaş B, Çelik AD (2018) Hatay ili Damızlık Sığır Yetiştiricileri Birliği Üyesi İşletmelerin SosyoEkonomik Özellikleri. Hay. Üret., 59 (1): 25-32.
Tatar, AM (2007) Ankara ve Aksaray Damızlık Sığır Yetiştiricileri î Birliklerine Üye Süt Sığırcılığı İşletmelerinin Yapısı ve Sorunları. Ankara Üniversitesi Fen Bilimleri Enstitüsü Doktora Tezi, 119 s. Ankara.

Yılmaz i, Kaylan V, Yanar M (2020) Iğdır İli Büyükbaş Hayvancılığının Yapısal Analizi. Iğdır Üniversitesi Fen Bil. Enst. Derg., 10(1): 684-693.

Yamane T (2010) Temel Örnekleme Yöntemleri. Literatür Yayıncılık, ISBN: 978-975-8431-34-2, ìstanbul. 